\title{
The practice patterns in the management of sebaceous carcinoma of the eyelid in the Asia Pacific region
}

\author{
Janice J. C. Cheung $\mathbb{1}^{1,2} \cdot$ Bita Esmaeli ${ }^{3}$ Stacey C. Lam ${ }^{4,5} \cdot$ Tracey Kwok ${ }^{4,5} \cdot$ Hunter K. L. Yuen ${ }^{4,5}$
}

Received: 31 January 2019 / Revised: 4 March 2019 / Accepted: 13 March 2019 / Published online: 5 April 2019

(c) The Royal College of Ophthalmologists 2019

\begin{abstract}
Purpose To determine the practice patterns of ophthalmic plastic surgeons regarding the management of eyelid sebaceous carcinoma (SC).

Methods An electronic survey was distributed to oculoplastic surgical colleagues in the Asia Pacific region requesting clinical information and treatment approaches to SC.

Results The responses from 192 respondents from the Asia Pacific region was included and analyzed in this study. For initial diagnosis, most surgeons selected incisional biopsy (55\%), followed by complete excision (35\%). Initial workup was mainly by palpation of lymph nodes, chest X-ray, and computerized tomography scan (CT-scan) of the orbit. Conjunctival map biopsy was done in selected cases. Sentinel lymph node biopsy (SLNB) was done mainly for tumors larger than $10 \mathrm{~mm}$. Management was mainly by surgical excision ( $5 \mathrm{~mm}$ margin) combined with adjuvant therapy in some cases, with radiotherapy being the most common. Margin status was determined most frequently by frozen section as evaluated by the pathologist (57\%) followed by Mohs micrographic surgery (18\%). Surveillance was based mainly on physical examination alone.

Conclusion The Asia Pacific oculoplastic surgeons prefer incisional biopsy for lesions suspicious of SC prior to definitive surgery. This is in contrast to survey results previously reported in other populations. Frozen section control (done by an oculoplastic surgeon with pathology support) is most commonly used for margin control and conjunctival map biopsies are done only in selected cases. Despite the potential benefits of SLNB, access and expertise in this area is currently lacking in the Asia Pacific region.
\end{abstract}

Supplementary information The online version of this article (https:// doi.org/10.1038/s41433-019-0432-0) contains supplementary material, which is available to authorized users.

$\square$ Janice J. C. Cheung

janicejccheung@yahoo.com.hk

1 Department of Ophthalmology, LKS Faculty of Medicine, The University of Hong Kong, Pokfulam, Hong Kong SAR, China

2 Department of Ophthalmology, Grantham Hospital, Aberdeen, Hong Kong SAR, China

3 Orbital Oncology and Ophthalmic Plastic Surgery, Department of Plastic Surgery, The University of Texas MD Anderson Cancer Center, Houston, TX, USA

4 Department of Ophthalmology, Hong Kong Eye Hospital, 147K Argyle Street, Kowloon, Hong Kong SAR, China

5 Department of Ophthalmology and Visual Sciences, The Chinese University of Hong Kong, Shatin, Hong Kong SAR, China

\section{Introduction}

Sebaceous carcinoma (SC) is the second most common malignant eyelid tumor following basal cell carcinoma in the Asian population [1] and the third most common following basal cell carcinoma and squamous cell carcinoma in the Caucasian population [2]. The reported incidence is higher in the Asian population than in the Caucasian population [3]. The incidence was found to be 0.32 in male and 0.1 in female per 100,000 person-years in the US [4]. SC constituted $1-5 \%$ of all malignant eyelid tumors in the US [5], 7.1-11.1\% in Hong Kong SAR [3, 6], 31.7\% in China [7], and 32.6\% in India [8].

It has been coined as the great masquerader due to its variable clinical presentations and multifocal nature in some cases. Difficulties in early recognition combined with its potentially aggressive behavior can lead to poor prognosis. The tumor-related mortality rate was reported 
at $6 \%$ during mean follow-up of 39.2 months with a 5 -year disease-specific survival rate of $92 \%$ in a study of 100 patients with SC [9]. With better understanding of the disease and improved histopathological techniques, early diagnosis has improved the overall outcome [10]. The mainstay of treatment is surgical excision with the aim of achieving negative microscopic margins. External beam radiotherapy, cryotherapy, and topical chemotherapy have been used as adjuvant treatment [5]. However, there is no clear consensus on many aspects of management of SC and clinical practice can vary greatly between different populations. Our study aims to identify some of these differences and explore the current practice patterns amongst oculoplastic surgeons in the Asia Pacific region in the management of eyelid SC.

\section{Methods}

A survey containing 40 questions regarding the demographics, training background, and practice patterns for management of SC of eyelid was constructed on the website kwiksurveys.com. The survey was in the format of multiple-choice questions and when appropriate, respondents were given the option of selecting one-best answer, multiple answers, or to specify their answer in free-text format. A copy of the survey can be found in Appendix A. Out of the 40 questions, 12 of them could have multiple answers. Respondents could skip questions if they wished to do so. The survey was electronically distributed via e-mail to members of the Asia Pacific Society of Oculoplastic and Reconstructive Surgery (APSOPRS), Hong Kong Society of Oculoplastic and Reconstructive Surgery (HKSOPRS), and individual oculoplastic society directories of the corresponding author. A follow-up e-mail was sent 1 month later as a reminder. The responses were extracted from the online platform and analyzed.

The study protocol was approved by the local institutional research ethics committee, Institutional Review Board of the Hospital Authority Hong Kong West Cluster. The study firmly adhered to the tenets of the 1964 Helsinki declaration and its later amendments.

\section{Results}

A total of 263 respondents participated in the survey. Among the 263 respondents, 9 were not from the Asia Pacific region and were excluded, while 63 responders answered fewer than 10 questions and were also excluded. The data from the remaining 192 responders were included in the study.

\section{Geographic distribution, training, and experience with SC of survey respondents}

See Table 1, Q.1-7. All respondents were from Asia Pacific countries, primarily Hong Kong (23\%), China (18\%), South Korea (10\%), and India (9\%). 68 (38\%) respondents practiced primarily in an academic institution and $62(35 \%)$ respondents in the public health care system. The respondents received their oculoplastic surgical training in various regions including the US (34, 18\%), Hong Kong (27, 14\%), and South Korea (18, 9\%). 86 (67\%) respondents managed fewer than five cases of SC per year, 26 (20\%) managed 5-10 cases per year while 17 (13\%) managed more than 10 cases annually. $30(24 \%)$ respondents had managed more than 40 cases of SC in their career. $96(36 \%)$ respondents thought that the most common presentation of SC was a painless eyelid mass and $81(30 \%)$ selected recurrent chalazion as the most common presentation.

\section{Reported practice patterns}

See Table 2, Q.8-31. In patients with suspected SC, 74 (55\%) surgeons selected an incisional biopsy as their preferred first intervention and $47(35 \%)$ respondents selected full thickness excisional biopsy as the initial step. 106 (35\%) respondents undertook physical examination with emphasis on lymph node palpation as work up for newly diagnosed SC. Of the remaining respondents, $81(27 \%)$ performed radiological imaging and 47 (16\%) ordered blood work up. Chest radiographs (CXR) and computed tomography (CT) orbit were the most preferred investigative modality regardless of size. $82(30 \%)$ respondents performed conjunctival map biopsy when there was clinical suspicion of pagetoid involvement of conjunctiva, $56(20 \%)$ in recurrent disease, and $52(19 \%)$ if both upper and lower eyelids were involved.

Intraoperatively, 36 (32\%) determined surgical margin for excision of SC based on frozen section findings, while $30(27 \%)$ respondents preferred to use $5 \mathrm{~mm}$ of clinical margin clearance. Margin clearance was based on frozen section evaluation by a pathologist according to 63 respondents $(57 \%)$ and Mohs micrographic surgery according to 20 respondents (18\%). After excision of SC, reconstruction of posterior lamella using lid sharing procedures was the preferred option of $51(46 \%)$ respondents for upper eyelid and $59(55 \%)$ respondents in lower eyelid.

Adjuvant treatment was selected by 71 (23\%) of respondents in the presence of positive margins after surgery. Among the adjuvant therapies, 44 (42\%) used radiotherapy and 39 (38\%) used topical Mitomycin-C (MMC). Regarding the use of MMC, 50 (48\%) respondents followed the regimen $0.04 \% \mathrm{MMC}$ four times daily for a week, 
Table 1 Demographics and training background

Q1. Where is the country of your clinical practice? (can tick more than one option)

$\begin{array}{lll}\text { Country } & N & \text { Percentage (\%) } \\ \text { Total respondents } & 129 & \\ \text { Hong Kong } & 30 & 23 \\ \text { China } & 23 & 18 \\ \text { South Korea } & 13 & 10 \\ \text { India } & 12 & 9 \\ \text { Philippines } & 11 & 9 \\ \text { Taiwan } & 11 & 9 \\ \text { Singapore } & 8 & 6 \\ \text { Japan } & 3 & 2 \\ \text { Nepal } & 2 & 2 \\ \text { Australia/New Zealand } & 3 & 2 \\ \text { Indonesia } & 9 & 7 \\ \text { Bangladesh } & 2 & 2 \\ \text { Pakistan } & 1 & 1 \\ \text { Mongolia } & 1 & 1\end{array}$

Q2. Which sector is your clinical practice in (tick as many as applicable)?

$\begin{array}{lll}\text { Respondents/total responses } & 129 / 177 & \\ \text { Public } & 62 & 35 \\ \text { Private } & 47 & 27 \\ \text { Academic Institution } & 68 & 38\end{array}$

Q3. How many years have you been practicing in your subspecialized in Oculoplastic surgery for?

$\begin{array}{lll}\text { Total respondents } & 129 & \\ <10 \text { years } & 37 & 29 \\ 10-20 \text { years } & 59 & 46 \\ 20-30 \text { years } & 28 & 22 \\ >30 \text { years } & 5 & 4 \\ \text { SD } & 19.42 & \end{array}$

Q4. Where did you receive your oculoplastic training (tick as many as applicable)?

\begin{tabular}{lll} 
Respondents/total responses & $129 / 193$ & \\
United States & 34 & 18 \\
Hong Kong & 27 & 14 \\
South Korea & 18 & 9 \\
China & 15 & 8 \\
India & 14 & 7 \\
Taiwan & 14 & 7 \\
Other (Please Specify) & 10 & 5 \\
Singapore & 9 & 5 \\
United Kingdom & 9 & 5 \\
Australia/New Zealand & 8 & 4 \\
Europe & 7 & 4 \\
Canada & 7 & 4 \\
China & 7 & 4 \\
Japan & 7 & 4 \\
& & \\
\hline
\end{tabular}

Table 1 (continued)

\begin{tabular}{lll}
\hline Indonesia & 3 & 2 \\
Philippines & 2 & 1 \\
Thailand & 1 & 1 \\
Bangladesh & 1 & 1 \\
Cambodia & 0 & 0
\end{tabular}

Q5. On average, how many new cases of SC do you manage per year?

$\begin{array}{lll}\text { Total responses } & 129 & \\ <5 & 86 & 67 \\ 5-10 & 26 & 20 \\ >10 & 17 & 13 \\ \text { SD } & 30.63 & \end{array}$

Q6. How many total cases of SC have you managed in your career thus far?

$\begin{array}{lll}\text { Respondents/total responses } & 124 / 123 & \text { Percentage (\%) } \\ <5 & 19 & 15 \\ 5-10 & 23 & 19 \\ 10-20 & 29 & 23 \\ 20-30 & 9 & 8 \\ 30-40 & 13 & 10 \\ >40 & 30 & 24 \\ \text { SD } & 7.5 & \end{array}$

Q7. From your experience, which is the most common presentation of SC (tick as many as applicable)?

\begin{tabular}{lll} 
Respondents/total responses & $129 / 268$ & \\
Painless eyelid mass & 96 & 36 \\
Blepharoconjuncitivitis & 35 & 13 \\
Recurrent chalazion & 81 & 30 \\
Diffuse eyelid thickening & 47 & 18 \\
Orbital signs & 7 & 3 \\
Systemic involvement & 1 & 0 \\
Others (bleeding mass) & 1 & 0 \\
\hline
\end{tabular}

followed by 1 week of rest. In cases with pagetoid spread but without metastasis, complete excision with frozen section control of margins combined with adjuvant therapy was the preferred approach of $84(78 \%)$ respondents and exenteration was preferred by $14(13 \%)$ respondents.

$46(42 \%)$ respondents never performed sentinel lymph node biopsy (SLNB), while 3 (3\%) performed SLNB in all of their cases. The remaining respondents performed SLNB in selected cases. Among those who performed SLNB, 26 (24\%) performed SLNB in patients with stage AJCC 7th edition TNM criteria T2b SC (greater than $10 \mathrm{~mm}$ ).

In locally advanced non-metastatic SC, 53 (51\%) respondents preferred surgical excision combined with adjuvant treatment. Among the neo-adjuvant agents used in globe preserving surgical excision for locally advanced SC, $21(21 \%)$ respondents preferred MMC. For recurrent disease, $50(48 \%)$ preferred surgical excision with adjuvant 
Table 2 Practice patterns and preferences in management of sebaceous carcinoma

\section{$N \quad$ Percentage $(\%)$}

Q8. In the cases of SC, what is your preferred technique of initial biopsy (tick as many as applicable)?

$\begin{array}{lll}\text { Respondents/total responses } & 112 / 135 & \\ \text { Incisional biopsy } & 74 & 55 \\ \text { Shave excisional biopsy } & 3 & 2 \\ \text { Full thickness excisional biopsy } & 47 & 35 \\ \text { Punch biopsy } & 5 & 4 \\ \text { Frozen section } & 4 & 3 \\ \text { FNAC } & 1 & 1 \\ \text { Conjunctival map biopsy } & 1 & 1\end{array}$

Q9. Which of the following do you routinely perform for workup for localized SC (tick as many as applicable)?

$\begin{array}{lll}\text { Respondents/total responses } & 112 / 304 & \\ \text { Blood taking } & 47 & 16 \\ \text { Radiological imaging } & 81 & 27 \\ \text { Lymph node palpation } & 106 & 35 \\ \text { Abdominal examination } & 30 & 10 \\ \text { Chest examination } & 36 & 12 \\ \text { Refer to oncologist for work up } & 2 & 1 \\ \text { Others } & 2 & 1\end{array}$

Q10. What imaging modality do you most commonly use on initial diagnosis of clinically localized $\mathrm{SC}<10 \mathrm{~mm}$ (tick as many as applicable)

$\begin{array}{lll}\text { Respondents/total responses } & 110 / 222 & \\ \text { Chest X-ray } & 40 & 18 \\ \text { CT orbit } & 38 & 17 \\ \text { MRI orbit } & 26 & 12 \\ \text { CT head } & 5 & 2 \\ \text { MRI head } & 6 & 3 \\ \text { CT head and neck } & 13 & 6 \\ \text { MRI head and neck } & 5 & 2 \\ \text { Ultrasound of regional lymph nodes } & 22 & 10 \\ \text { (parotid and submandibular lymph } & & \\ \text { nodes) with FNA as needed } & & \\ \text { Ultrasound liver } & 16 & 7 \\ \text { CT liver } & 4 & 2 \\ \text { Whole body PET CT scan } & 18 & 8 \\ \text { CT chest } & 0 & 0 \\ \text { None } & 26 & 12 \\ \text { Others } & 3 & 1\end{array}$

Q11. What imaging modality do you most commonly use on initial diagnosis of clinically localized $\mathrm{SC}>10 \mathrm{~mm}$ (tick as many as applicable)

$\begin{array}{lll}\text { Respondents/total responses } & 111 / 300 & \\ \text { Chest X-ray } & 45 & 16 \\ \text { CT orbit } & 53 & 19 \\ \text { MRI orbit } & 37 & 13 \\ \text { CT head } & 6 & 2\end{array}$

Table 2 (continued)

\begin{tabular}{lll}
\hline & $N$ & Percentage (\%) \\
\hline MRI head & 8 & 3 \\
CT head and neck & 21 & 8 \\
MRI head and neck & 20 & 7 \\
Ultrasound of regional lymph nodes & 31 & 11 \\
(parotid and submandibular lymph & & \\
nodes) with FNA as needed & & \\
Ultrasound liver & 27 & 10 \\
CT liver & 7 & 3 \\
Whole body PET CT scan & 38 & 14 \\
CT chest & 1 & 0 \\
None & 4 & 2 \\
Others & 2 & 1
\end{tabular}

Q12. In cases of SC, when do you perform conjunctival map biopsies? (tick as many as applicable)

$\begin{array}{lll}\text { Respondents/total responses } & 111 / 274 & \\ \begin{array}{l}\text { Suspicious of pagetoid involvement of } \\ \text { conjunctiva }\end{array} & 82 & 30 \\ \text { Recurrent disease } & 56 & 20 \\ \text { Upper and lower eyelid involvement } & 52 & 19 \\ \text { Orbital spread } & 29 & 11 \\ \text { Large tumor size } & 40 & 15 \\ \text { Never } & 11 & 4 \\ \text { Always } & 3 & 1 \\ \text { Others } & 1 & 0\end{array}$

Q13. What size margin do you usually excise for SC?

$\begin{array}{lll}\text { Total responses } & 111 & \\ 3 \mathrm{~mm} & 20 & 18 \\ 4 \mathrm{~mm} & 19 & 17 \\ 5 \mathrm{~mm} & 30 & 27 \\ 6 \mathrm{~mm} & 4 & 4 \\ >6 \mathrm{~mm} & 2 & 2 \\ \text { According to frozen section findings } & 36 & 32 \\ \text { SD } & 12.41 & \end{array}$

Q14. Which is your preferred method of assessment of margin involvement after excision?

Total responses

111

Send specimen for frozen section by 63 pathologist

$\begin{array}{lll}\text { En face frozen section } & 7 & 6 \\ \text { Moh's micrographic surgery } & 20 & 18 \\ \begin{array}{l}\text { Permanent section with subsequent } \\ \text { eyelid reconstruction }\end{array} & 15 & 14 \\ \text { Rapid paraffin section } & 5 & 5\end{array}$

SD 20.4

Q15. In upper eyelid reconstruction after wide excision, which of the following is your preferred choice for posterior lamellar reconstruction?

$\begin{array}{lll}\text { Total responses } & 110 \\ \text { Lid sharing procedure } & 51 & 46\end{array}$ 
Table 2 (continued)

\begin{tabular}{lll}
\hline & $N$ & Percentage (\%) \\
\hline Graft from fellow eyelid & 24 & 22 \\
Graft from distal sites (i.e., hard palate, & 27 & 25 \\
ear cartilage, etc.) & & \\
Synthetic graft & 3 & 3 \\
Scleral graft & 2 & 2 \\
Others & 3 & 3
\end{tabular}

Q16. In lower eyelid reconstruction after wide excision, which of the following is your preferred choice for posterior lamellar reconstruction?

$\begin{array}{lll}\text { Total responses } & 107 & \\ \text { Lid sharing procedure } & 59 & 55 \\ \text { Graft from fellow eyelid } & 12 & 11 \\ \text { Graft from distal sites (i.e., hard palate, } & 27 & 25 \\ \text { ear cartilage, etc.) } & & \\ \text { Synthetic graft } & 2 & 2 \\ \text { Scleral graft } & 3 & 3 \\ \text { Others } & 4 & 4 \\ \text { SD } & 18.83\end{array}$

Q17. When do you use adjuvant treatment? (tick as many as applicable)

$\begin{array}{lll}\text { Respondents/total responses } & 110 / 313 & \\ \text { Pagetoid involvement of conjunctiva } & 63 & 20 \\ \text { Recurrent disease } & 51 & 16 \\ \text { Upper and lower eyelid involvement } & 26 & 8 \\ \text { Positive margins after surgery } & 71 & 23 \\ \text { Orbital spread } & 67 & 21 \\ \text { Large tumor size } & 25 & 8 \\ \text { Lymph node metastasis } & 2 & 1 \\ \text { Never } & 6 & 2 \\ \text { Others } & 2 & 1\end{array}$

Q18. Which adjuvant do you commonly use?

Total responses

Cryotherapy

$\begin{array}{ll}39 & 38 \\ 15 & 14 \\ 44 & 42 \\ 1 & 1 \\ 4 & 4 \\ 1 & 1 \\ 15.92 & \end{array}$

Radiotherapy

Chemotherapy

Refer to oncologist/cancer unit

Others

SD

Q19. For mitomycin C, what is your regimen of choice?

Total responses 105

$0.04 \%$ Mitomycin-C four times daily for a week followed by one week off in one cycle

Others

Not applicable

SD

$50 \quad 48$

$3 \quad 3$

$52 \quad 50$

22.64
Table 2 (continued)

$N \quad$ Percentage $(\%)$

Q20. On average, how many cycles for mitomycin $\mathrm{C}$ do you use? (e.g., one cycle $=$ one week on and one week off)

Total responses

106

One

Two

Three

$6 \quad 6$

Four

$10 \quad 9$

More than four

109

Not applicable

$22 \quad 21$

$\mathrm{SD}$

$56 \quad 53$

18.2

Q21. In cases with pagetoid spread (intraepithelial neoplasia) without metastasis, what is your preferred primary treatment?

Total responses 108

Wide local excision combined with $\quad 84 \quad 78$ adjuvant therapy

Exenteration

$14 \quad 13$

Topical chemotherapy and close

87

observation

Wide excision only

$2 \quad 2$

SD

31.93

Q22. When do you treat eyelid SC with radiotherapy as primary treatment? (tick as many as applicable)

$\begin{array}{lll}\text { Respondents/total responses } & 109 / 224 & \\ \text { Patient refuses surgery } & 55 & 25 \\ \text { Patient is surgically unfit } & 59 & 26 \\ \begin{array}{l}\text { As palliative treatment in advanced } \\ \text { disease }\end{array} & 62 & 28 \\ \text { Lack of surgical support } & 14 & 6 \\ \text { As neo-adjuvant treatment before } & 10 & 5 \\ \text { surgery } & & \\ \text { Surgeon's preference } & 5 & 2 \\ \text { Never } & 19 & 9\end{array}$

Q23. When do you perform sentinel lymph node biopsy (SLN Bx)? Total responses

109

All cases

$3 \quad 3$

Size $>5 \mathrm{~mm}$

$10 \quad 9$

Size $>10 \mathrm{~mm}$

$26 \quad 24$

Size $>20 \mathrm{~mm}$

$17 \quad 16$

When there is palpable lymph nodes $\quad 1 \quad 1$

Imaging shows lymph node involvement $3 \quad 3$

Never $\quad 46 \quad 42$

Others $3 \quad 3$

Q24. In cases with regional nodal metastasis without distant metastasis, what is your preferred treatment?

Total responses

105

Lymph node dissection alone

$9 \quad 9$

$51 \quad 49$ 
Table 2 (continued)

\begin{tabular}{lll}
\hline & $N$ & Perce \\
\hline $\begin{array}{l}\text { Lymph node dissection followed by } \\
\text { radiotherapy if indicated }\end{array}$ & & \\
$\begin{array}{l}\text { Lymph node dissection combined with } \\
\text { chemotherapy }\end{array}$ & 21 & 20 \\
$\begin{array}{l}\text { Chemotherapy alone } \\
\text { Radiotherapy alone }\end{array}$ & 2 & 2 \\
$\begin{array}{l}\text { Combined chemotherapy and } \\
\text { radiotherapy }\end{array}$ & 2 & 2 \\
$\begin{array}{l}\text { Refer to other specialist } \\
\text { SD }\end{array}$ & 7 & 12 \\
\end{tabular}

Q25. In locally advanced non-metastatic SC, which is your preferred primary treatment modality?

$\begin{array}{lll}\begin{array}{l}\text { Total responses } \\ \text { Surgical excision combined with }\end{array} & 105 & \\ \begin{array}{l}\text { adjuvant treatment } \\ \text { Neoadjuvant chemotherapy followed by }\end{array} & 12 & 11 \\ \begin{array}{l}\text { surgery } \\ \begin{array}{l}\text { Exenteration } \\ \text { SD }\end{array}\end{array} & 40 & 38 \\ & 17.11 & \end{array}$

Q26. Which neo-adjuvant agent do you use for globe preserving surgical excision in cases of locally advanced SC? (tick as many as applicable)

$\begin{array}{lll}\text { Respondents/total responses } & 101 / 102 & \\ \text { Cisplatin } & 9 & 9 \\ \text { Carboplatin } & 4 & 4 \\ \text { 5-Fluorouracil } & 9 & 9 \\ \text { Docetaxel } & 0 & 0 \\ \text { Mitomycin-C } & 21 & 21 \\ \text { Hormonal therapy } & 0 & 0 \\ \text { Do not use } & 47 & 46 \\ \text { Decided by oncologist } & 12 & 12 \\ \text { SD } & 14.57 & \end{array}$

Q27. In cases requiring exenteration, what is your preferred technique?

$\begin{array}{lll}\text { Total responses } & 104 & \\ \begin{array}{l}\text { Skin sparing approach (if skin not } \\ \text { involved) }\end{array} & 21 & 20 \\ \text { Total exenteration } & 26 & 25 \\ \text { Subtotal exenteration } & 10 & 10 \\ \text { Depends on extent of disease } & 47 & 45 \\ \text { Other } & 0 & 0 \\ \text { SD } & 15.89 & \end{array}$

Q28. In cases requiring exenteration, what is your preferred technique for wound closure?

$\begin{array}{lll}\text { Healing by granulation } & 41 & 39 \\ \text { Skin graft } & 16 & 15 \\ \text { Local skin flap } & 9 & 9 \\ \begin{array}{l}\text { Depends on extent of disease and need } \\ \text { for post-operative radiotherapy }\end{array} & 37 & 35\end{array}$

Table 2 (continued)

\begin{tabular}{lll}
\hline & $N$ & Percentage $(\%)$ \\
\hline Synthetic material & 2 & 2 \\
Total & 105 & \\
SD & 15.17 &
\end{tabular}

Q29. In cases with widespread non-metastatic disease requiring exenteration, which is your preferred treatment after exenteration?

$\begin{array}{lll}\text { Total responses } & 104 & \\ \text { Radiotherapy } & 30 & 29 \\ \text { Chemotherapy } & 4 & 4 \\ \text { Both } & 13 & 13 \\ \begin{array}{l}\text { Depending on specimen findings after } \\ \text { exenteration }\end{array} & 55 & 53 \\ \text { Decided by oncologist } & & \\ \text { SD } & 2 & 2 \\ \text { Q30.75 } & 19.75\end{array}$

Q30. In patients with recurrent disease, which is your preferred treatment?

\begin{tabular}{|c|c|}
\hline Total responses & 105 \\
\hline $\begin{array}{l}\text { Neoadjuvant treatment followed by } \\
\text { surgical excision }\end{array}$ & 8 \\
\hline $\begin{array}{l}\text { Surgical excision with adjuvant } \\
\text { treatment }\end{array}$ & 50 \\
\hline Surgical excision alone & 2 \\
\hline Exenteration alone & 10 \\
\hline $\begin{array}{l}\text { Exenteration combined with } \\
\text { radiotherapy }\end{array}$ & 24 \\
\hline $\begin{array}{l}\text { Exenteration combined with } \\
\text { chemotherapy }\end{array}$ & 8 \\
\hline Other & 3 \\
\hline SD & 15.72 \\
\hline
\end{tabular}

Q31. In patients with localized SC who are not fit for surgery or refuse surgery, what is your primary management?

$\begin{array}{lll}\text { Total responses } & 106 & \\ \text { Radiotherapy } & 70 & 66 \\ \text { Chemotherapy } & 13 & 12 \\ \text { Cryotherapy } & 15 & 14 \\ \text { Observe } & 4 & 4 \\ \text { Others } & 4 & 4 \\ \text { SD } & 24.81 & \end{array}$

therapy and $24(23 \%)$ preferred exenteration combined with radiotherapy.

\section{Outcomes}

See Table 3, Q.32-34. According to their experience, 42 (40\%) respondents estimated a recurrence rate of less than $10 \%$ in patients with localized SC. $52(50 \%)$ of respondents estimated the overall mortality rate from SC as less than 5\%. $62(61 \%)$ of respondents selected distant metastatic disease as the most common cause of death in patients with SC. 
Table 3 Results and outcomes based on personal experience

$N \quad$ Percentage $(\%)$

Q32. From your experience, what is the approximate recurrence rate of localized SC?

$\begin{array}{lll}\text { Total responses } & 105 & \\ <10 \% & 42 & 40 \\ 10-20 \% & 30 & 28 \\ 20-30 \% & 10 & 9 \\ 30-40 \% & 6 & 6 \\ >40 \% & 2 & 2 \\ \text { Not sure } & 15 & 14 \\ \text { SD } & 14.09 & \end{array}$

Q33. From your experience, what is the approximate overall mortality rate from SC?

$\begin{array}{lll}\text { Total responses } & 104 & \\ <5 \% & 52 & 50 \\ 5-10 \% & 19 & 18 \\ 10-20 \% & 6 & 6 \\ >20 \% & 5 & 5 \\ \text { Not sure } & 22 & 21 \\ \text { SD } & 17.01 & \end{array}$

Q34. From your experience, what is the main cause of death in your patients with SC?

\begin{tabular}{lll} 
Total responses & 101 & \\
Localized disease & 1 & 1 \\
Regional metastatic disease & 9 & 9 \\
Distant metastatic disease & 62 & 61 \\
Side effects of treatment & 1 & 1 \\
Other cases (such as medical comorbidities) & 28 & 28 \\
SD & 23.11 & \\
\hline
\end{tabular}

\section{Follow-up}

See Table 4, Q.35-37. From our survey, 65 (64\%) respondents routinely referred patients for assessment by a medical oncologist and $37(36 \%)$ did not. $38(37 \%)$ of respondents used physical examination alone during surveillance. 75 (74\%) of respondents reported that long-term surveillance for local control was carried out by oculoplastic surgeons.

\section{Discussion}

Consistent with the well-known higher incidence of SC in the Asia Pacific countries [1, 5, 11, 12], many of our respondents seem to be more experienced in managing SC compared with the average non-Asian oculoplastic surgeon and up to $24 \%$ have managed more than 40 cases in their career so far.

In keeping with previous studies in the Asia Pacific population, the main presenting symptom of $\mathrm{SC}$ as reported
Table 4 Practice patterns in follow-up care and surveillance of sebaceous carcinoma

$$
N \quad \text { Percentage }(\%)
$$

Q35. Do you routinely refer patients with SC for oncologist assessment?

$\begin{array}{lll}\text { Total responses } & 102 & \\ \text { Yes } & 65 & 64 \\ \text { No } & 37 & 36 \\ \text { SD } & 14 & \end{array}$

Q36. Which investigation do you perform after surgery during surveillance?

$\begin{array}{lll}\text { Total responses } & 103 & \\ \text { CT scan } & 27 & 26 \\ \text { MRI } & 29 & 28 \\ \text { Ultrasound } & 6 & 6 \\ \text { Physical exam alone } & 38 & 37 \\ \text { PET CT scan } & 2 & 2 \\ \text { Other } & 1 & 1 \\ \text { SD } & 1222 & \end{array}$

Q37. For the majority of stable cases, long-term surveillance is done by

$\begin{array}{lll}\text { Total responses } & 102 & \\ \text { Oculoplastic surgeon } & 75 & 74 \\ \text { General ophthalmologist } & 10 & 10 \\ \text { Oncologist } & 16 & 16 \\ \text { Primary care physician } & 1 & 1 \\ \text { SD } & 29.07 & \end{array}$

by our respondents was a solitary eyelid nodule (36\%) [13-15]. Diffuse eyelid thickening mimicking blepharoconjunctivitis was reported by $13 \%$ of our respondents, which is less than the Caucasian population [16, 17]. Since nodular presentation such as recurrent chalazion is more common, incisional biopsy together with incision and curettage is commonly performed. This could explain why our respondents most commonly performed incisional biopsy (55\%) followed by full thickness excisional biopsy (35\%). This is different from a recently published British cohort in which primary excisional biopsy was the most commonly performed diagnostic intervention (42\%) followed by incisional wedge biopsy (33\%) [18].

We found there was no consensus amongst respondents on the investigative modality used for disease staging. More respondents chose $\mathrm{CT}$ orbit over MRI orbit, perhaps due to the availability and affordability of CT over MRI. Some series suggest map biopsies for all cases because even in solitary nodular SC with no conjunctival involvement clinically, half had biopsy-proven conjunctival involvement [19]. Others perform map biopsy only if there is clinical suspicion of diffuse palpebral and bulbar conjunctival involvement [20]. Our respondents performed conjunctival map biopsy in selected cases, most commonly 
those with clinical signs suggestive of pagetoid involvement of conjunctiva (30\%), recurrent disease $(20 \%)$, and both upper and lower eyelid involvement (19\%). Sa et al. [9] carried out a retrospective study of predominantly White and Hispanic subjects in the US and found among the 100 patients diagnosed with SC, 31 patients had intraepithelial neoplasia and this finding was mostly based on evaluation of the surgical specimen rather than conjunctival map biopsies; these authors advocate for conjunctival map biopsies only in selected patients who have clinically suspicious signs of involvement of conjunctiva adjacent to the main tumor. Yoon et al. [15] found only $8.3 \%$ of their Korean patients with SC had pagetoid spread. SC may behave differently in terms of its clinical presentation and tendency for pagetoid spread between different ethnicities.

We found that most respondents rely on physical examination as the main method for the detection of lymph node metastasis. For lesions greater than $10 \mathrm{~mm}, 24 \%$ of respondents would perform SLNB and 9\% would perform SLNB for lesions greater than $5 \mathrm{~mm}$. The relatively low percentage of SLNB performed in the Asia Pacific region may be related to the lack of technical expertise at certain centres and it may also be due to the fact that SLNB is logistically time consuming to set up. Among our respondents, $10 \%$ and $11 \%$ of respondents would evaluate regional lymph nodes with ultrasonography and perform fine needle aspiration as needed in lesions less than $10 \mathrm{~mm}$ and greater than $10 \mathrm{~mm}$, respectively. Ultrasonography is a relatively inexpensive and accurate way of assessing for nodal involvement [21] and can be considered if SLNB is not available. Since SC metastasize to regional and systemic lymph nodes, ultrasonography of parotid, submandibular and cervical lymph nodes, and SLNB have been suggested as a way to evaluate regional lymph nodes to rule out metastasis. Studies have demonstrated that tumors larger than $10 \mathrm{~mm}$ correlate with nodal metastasis and this can occur in up to $18 \%$ [14, 16, 21]. Watanabe et al. [13] found that even tumors less than $5 \mathrm{~mm}$ can be associated with regional nodal metastasis among their Japanese cohort. Routine SLNB requires special expertise and can yield false negative results early in the learning curve, but the accuracy of SLNB for eyelid tumors has improved considerably in the past decade $[22,23]$. The overall SLNB positivity rate was reported at $13 \%$ by the MD Anderson Cancer Center and all cases with positive SLNB had SC lesions greater than $10 \mathrm{~mm}$ [23, 24]. In a large series of 51 eyelid and conjunctival melanomas, $30 \%$ of patients with eyelid melanoma had positive SLNB [22]. This highlights the importance of SLNB in ocular adnexal malignancies.

According to our survey, the majority of responders (32\%) utilized frozen section to determine the size of excision margin with $27 \%$ using a $5 \mathrm{~mm}$ clinical excision margin. This is consistent with previous studies using an excision margin of $5 \mathrm{~mm}$ [14]. To assess for margin involvement, frozen section is the most commonly employed technique (57\%) followed by Mohs micrographic surgery $(18 \%)$. Most oculoplastic surgeons use a similar technique and principle to Mohs surgery in the eyelid area but removing the main tumor specimen as a full thickness "wedge" resection and then taking small en-face (adjacent) margins next to the main tumor specimen until negative margins are achieved. Our survey respondents used Mohs surgery more frequently than the British cohort, in which only $8 \%$ utilized Mohs surgery [18]. Mohs surgery, in common with all techniques that use frozen section evaluation of margins carries the risk of missing intraepithelial pagetoid spread and skip lesions [25]. The long-term benefits of Mohs surgery compared with other techniques is still unknown [26]. Full-thickness en-face frozen section has also been shown to be effective with comparable results to Mohs surgery for basal cell carcinoma [27, 28]. In a recent report from MD Anderson Cancer Center, using complete surgical excision of SC with en-face margin evaluation on frozen section, the local recurrence rate was only $6 \%$ [9]. In 4 of the 6 patients who experienced local recurrence in this 100-patient cohort, the surgeon had knowingly left a microscopically positive margin in an effort to avoid an orbital exenteration and MMC was given instead. This suggests that frozen section control using enface margins can yield comparable results to Mohs surgery [29]. Despite not being commonly employed by our respondents, local resection with rapid paraffin section analysis has been employed in some studies and offered low recurrence rates with good cosmetic outcome. Its advantage is that paraffin sections may be more reliable than frozen sections for detection of intraepithelial pagetoid spread and margin evaluation according to some reports [30].

In our survey, radiotherapy, topical MMC, and cryotherapy were the most preferred adjuvant therapies ( $42 \%$, $38 \%$, and $14 \%$, respectively). Shields et al. used cryotherapy after local excision in $68 \%$ of their patients and report a recurrence rate of $18 \%$ [16]. The use of MMC was adopted by $47 \%$ of our respondents. The most common regimen used was $0.04 \%$ Mitomycin-C four times daily for a week followed by one week off in one cycle used for four cycles. This is similar to the regimen used by Shields et al. [31] for patients with proven pagetoid involvement of the conjunctiva. Chemotherapy combined with surgical excision may be used in cases with extensive disease, nodal involvement, metastasis and occasionally in recurrent cases [32]. However, $46 \%$ of our respondents do not use neo-adjuvant chemotherapy for globe-preservation in locally advanced SC. Neo-adjuvant chemotherapy such as 5-fluorouracil and cisplatin may have a role in downstaging disease and avoiding more radical surgery, but current evidence is mostly limited to case reports and small case series [33, 34]. 
Based on their experience, the majority of our respondents report a recurrence rate of under $20 \%$ and a mortality rate of under $10 \%$, with distant metastatic disease as the most common cause of death. This appears to be in keeping with other studies $[9,10,14,16]$. Our survey suggests that most practitioners prefer a multidisciplinary approach in managing patients with SC, with up to $64 \%$ of surgeons routinely referring patients for assessment by an oncologist.

Our study is the first study to date to analyze the various practice patterns of oculoplastic surgeons in the Asia Pacific region. Limitations of this study include the nature of survey, which relies on the surgeon's impressions and estimation of events, rather than actual surgical outcomes. There is a definite possibility of selection and recall bias.

SC can have variable clinical presentations and may also behave differently in different ethnicities, explaining the variation in practice and management. Our survey highlights some differences in practice patterns in the Asia Pacific region compared with other populations. In particular, SC favors a nodular presentation in the Asia Pacific region. Initial diagnostic intervention and approach to conjunctival map biopsy may be different. We also found that SLNB is less commonly performed, possibly due to lack of access and expertise.

\section{Summary}

\section{What was known before}

- Sebaceous carcinoma has variable clinical presentations and management practices can vary greatly between surgeons and institutions.

- Mainstay treatment includes excision with adequate margins, radiotherapy, cryotherapy, and topical chemotherapy.

\section{What this study adds}

- This study explores the practice patterns of surgeons in Asia Pacific and how this compares with other populations.

- Incisional biopsy is commonly performed, conjunctival map biopsies are performed in selected cases, while Mohs micrographic surgery and sentinel lymph node biopsy are less widely available.

\section{Compliance with ethical standards}

Conflict of interest The authors declare that they have no conflict of interest.
Publisher's note: Springer Nature remains neutral with regard to jurisdictional claims in published maps and institutional affiliations.

\section{References}

1. Xu XL, Li B, Sun XL, Li LQ, Ren RJ, Gao F, et al. Eyelid neoplasms in the Beijing Tongren Eye Centre between 1997 and 2006. Ophthalmic Surg Lasers Imaging. 2008;39:367-72.

2. Deprez M, Uffer S. Clinicopathological features of eyelid skin tumors. A retrospective study of 5504 cases and review of literature. Am J Dermatopathol. 2009;31:256-62.

3. Ho M, Liu DT, Chong KK, Ng HK, Lam DS. Eyelid tumours and pseudotumours in Hong Kong: a ten-year experience. Hong Kong Med J. 2013;19:150-5.

4. Tripathi R, Chen Z, Li L, Bordeaux JS. Incidence and survival of sebaceous carcinoma in the United States. J Am Acad Dermatol. 2016;75:1210-5.

5. Shields JA, Demirci H, Marr BP, Eagle RC Jr., Shields CL. Sebaceous carcinoma of the ocular region: a review. Surv Ophthalmol. 2005;50:103-22.

6. Mak ST, Wong AC, Io IY, Tse RK. Malignant eyelid tumors in Hong Kong 1997-2009. Jpn J Ophthalmol. 2011;55:681-5.

7. Ni Z. Histopathological classification of 3,510 cases with eyelid tumor. Chin J Ophthalmol. 1996;32:435-7.

8. Sihota R, Tandon K, Betharia SB, Arora R. Malignant eyelid tumors in an Indian population. Arch Ophthalmol. 1996;114:108-9.

9. Sa HS, Rubin ML, Xu S, Ning J, Tetzlaff M, Sagiv O, et al. Prognostic factors for local recurrence, metastasis and survival for sebaceous carcinoma of the eyelid: observations in 100 patients. Br J Ophthalmol. 2018;0:1-5.

10. Muqit MMK, Roberts F, Lee WR, Kemp E. Improved survival rates in sebaceous carcinoma of the eyelid. Eye. 2004;18:49.

11. Abdi U, Tyagi N, Maheshwari V, Gogi R, Tyagi SP. Tumours of eyelid: a clinicopathologic study. $\mathrm{J}$ Indian Med Assoc. 1996;94:405-9.

12. Obata H, Aoki Y, Kubota S, Kanai N, Tsuru T. [Incidence of benign and malignant lesions of eyelid and conjunctival tumors]. Nippon Ganka Gakkai Zasshi. 2005;109:573-9.

13. Watanabe A, Sun MT, Pirbhai A, Ueda K, Katori N, Selva D. Sebaceous carcinoma in Japanese patients: clinical presentation, staging and outcomes. Br J Ophthalmol. 2013;97:1459-63.

14. Lam SC, Li EYM, Yuen HKL. 14-Year case series of eyelid sebaceous gland carcinoma in Chinese patients and review of management. Br J Ophthalmol. 2018;102:1723-7.

15. Yoon JS, Kim SH, Lee CS, Lew H, Lee SY. Clinicopathological analysis of periocular sebaceous gland carcinoma. Ophthalmologica. 2007;221:331-9.

16. Shields JA, Demirci H, Marr BP, Eagle RC Jr., Shields CL. Sebaceous carcinoma of the eyelids: personal experience with 60 cases. Ophthalmology. 2004;111:2151-7.

17. Zurcher M, Hintschich C, Garner A, Bunce C, Collin J. Sebaceous carcinoma of the eyelid: a clinicopathological study. Br J Ophthalmol. 1998;82:1049-55.

18. Muqit MM, Foot B, Walters SJ, Mudhar HS, Roberts F, Rennie IG. Observational prospective cohort study of patients with newly-diagnosed ocular sebaceous carcinoma. Br J Ophthalmol. 2013;97:47-51.

19. McConnell LK, Syed NA, Zimmerman MB, Carter KD, Nerad JA, Allen RC, et al. An analysis of conjunctival map biopsies in sebaceous carcinoma. Ophthalmic Plast Reconstr Surg. 2017;33:17-21.

20. Shields JA, Saktanasate J, Lally SE, Carrasco JR, Shields CL. Sebaceous carcinoma of the ocular region: the 2014 Professor Winifred Mao Lecture. Asia Pac J Ophthalmol. 2015;4:221-7. 
21. Esmaeli B, Nasser QJ, Cruz H, Fellman M, Warneke CL, Ivan D. American Joint Committee on Cancer $\mathrm{T}$ category for eyelid sebaceous carcinoma correlates with nodal metastasis and survival. Ophthalmology. 2012;119:1078-82.

22. Pfeiffer ML, Ozgur OK, Myers JN, Peng A, Ning J, Zafereo ME, et al. Sentinel lymph node biopsy for ocular adnexal melanoma. Acta Ophthalmol. 2017;95:e323-8.

23. Pfeiffer ML, Savar A, Esmaeli B. Sentinel lymph node biopsy for eyelid and conjunctival tumors: what have we learned in the past decade? Ophthalmic Plast Reconstr Surg. 2013;29:57-62.

24. Hui K-H, Pfeiffer ML, Esmaeli B. Value of positron emission tomography/computed tomography in diagnosis and staging of primary ocular and orbital tumors. Saudi J Ophthalmol. 2012;26:365-71.

25. Khan JA, Doane JF, Grove AS Jr. Sebaceous and meibomian carcinomas of the eyelid. Recognition, diagnosis, and management. Ophthalmic Plast Reconstr Surg. 1991;7:61-6.

26. Zhou C, Wu F, Chai P, Shi Y, Ye J, Shi X, et al. Mohs micrographic surgery for eyelid sebaceous carcinoma: a multicenter cohort of 360 patients. J Am Acad Dermatol. 2019. [Epub ahead of print].

27. Gill HS, Moscato EE, Seiff SR. Eyelid margin basal cell carcinoma managed with full-thickness en-face frozen section histopathology. Ophthalmic Plast Reconstr Surg. 2014;30:15-9.
28. Menesi W, Buchel EW, Hayakawa TJE. A reliable frozen section technique for basal cell carcinomas of the head and neck. Plast Surg. 2014;22:179-82.

29. Snow SN, Larson PO, Lucarelli MJ, Lemke BN, Madjar DD. Sebaceous carcinoma of the eyelids treated by mohs micrographic surgery: report of nine cases with review of the literature. Dermatol Surg. 2002;28:623-31.

30. While B, Salvi S, Currie Z, Mudhar HS, Tan JH. Excision and delayed reconstruction with paraffin section histopathological analysis for periocular sebaceous carcinoma. Ophthalmic Plast Reconstr Surg. 2014;30:105-9.

31. Shields CL, Naseripour M, Shields JA, Eagle RC Jr. Topical mitomycin- $\mathrm{C}$ for pagetoid invasion of the conjunctiva by eyelid sebaceous gland carcinoma. Ophthalmology. 2002;109:2129-33.

32. Kyllo RL, Brady KL, Hurst EA. Sebaceous carcinoma: review of the literature. Dermatol Surg. 2015;41:1-15.

33. Kaliki S, Ayyar A, Nair AG, Mishra DK, Reddy VA, Naik MN. Neoadjuvant systemic chemotherapy in the management of extensive eyelid sebaceous gland carcinoma: a study of 10 cases. Ophthalmic Plast Reconstr Surg. 2016;32:35-9.

34. Shields JA, Shields CL, Demirci H, Honavar SG, Singh AD. Experience with eyelid-sparing orbital exenteration: the 2000 Tullos O. Coston Lecture. Ophthalmic Plast Reconstr Surg. 2001;17:355-61. 